\title{
德育工作，智慧领航
}

\author{
吴要静 \\ 苏州工业园区青剑湖学校 \\ D O I:10.32629/jief.v2i1.458
}

[摘 要] 现代教育理念提倡“德、智、体、美、劳” 全面发展 ““德”在其中居于首位，所以德育的重要性可见一斑。本从四方面出发 : 在 教师的示范引领中开展德育; 在课堂中挖掘德育; 在实践中渗透德育; 在主题活动中升华德育, 针对小学生的德育教育提出的几点看法和 建议。

[关键词] 小学生 ; 德育 ; 途径

在素质教育的体系中, 德育是重要的组成部分, 尤其对小学生来说, 德育教育的影响极其深远。正因为德育对一个人的影响巨大, 德育工作不 仅仅是班主任老师的事情, 所有教师都应是德育人, 都是学生德育的导师。 在学生品德和品行打基础的小学阶段, 如何实施有效德育, 需要教师用智 慧展开。德育工作, 智慧领航, 是每一位教师教育生命中重要的思考话题。

\section{1 在教师的示范引领中开展德育}

德育不是简单的传授, 更不是简单的讲解, 德育在学生成长的无形 角落里, 需要教师的潜移默化, 润物细无声的浸润德育教育。

对于小学生而言, 他们有着很强的模仿能力, 思维记忆方式更多的 还以形象思维为主, 他们善于观察, 观察老师的一言一行, 也正因为对老 师的崇拜, 他们更善于捕捉教师的一举一动, 教师要充分了解学生的这一 特点, 用自己的一言一行来影响学生, 感染学生, 促动学生。这就要求教 师不仅仅有高深的专业知识, 更要求教师有高尚的师德, 高雅的气质。在 学生德育引领过程中, 通过积极的榜样作用渗透德育。用教师的人格魅力 和教师自身的知识修养来影响学生, 学生看在眼里, 既存在敬佩感, 又会 自然而然的跟着老师学。比如在教育语言中要注意经常用一些: “请”、“谢 谢”、“您可以” 等等词语与学生交流。在学生遇到困难时, 教师要和孩子 说: “只要肯努力你一定可以”、“老师相信你”、“世上无难事只怕有心人”, 教师首先要做一个阳光向上的人, 通过自己的行动和有爱的教育语言来激 励学生, 这种示范作用会在无形中给学生生命成长的力量, 让学生在学习 生活中一点一滴的进取, 一点一滴的改变。

\section{2 在课堂中挖掘德育}

课堂不仅仅是教师的讲授和学生的听课, 课堂更应该是教师渗透德 育的主阵地。无论任何一门学科, 都有德育的要素可挖掘, 只要教师用心, 都可以从教材中挖掘和德育相关的素材加以运用。教师要多钻研备课, 从 细节处找寻本学科对学生德育成长有价值的要素, 并加以开发和利用, 并 在充分调查了解学情的基础上结合具体的情境对学生进行德育教育, 实现 传授知识的同时, 将思想品德教育引入学生新田, 最终实现学生学业和品 行的双丰收。

就我所从事的体育课堂而言, 有很多地方都可以渗透德育。比如学 生的合作意识, 比如学生对公共器材的爱护意识, 比如同学之间的团结有 爱等等, 教师都可以借助体育课对学生进行引导教育, 在这个过程中教育 是无声的, 但却会在学生心中留下深刻的印象, 对学生引领是微妙的, 有 效的。

只有依托于课堂的德育才会有着旺盛的生命力, 只有与知识融合的 德育才更值得开发。任何一门学科都有很多德育要素有待挖掘, 只要教师 做到细致入微就一定可以找到开发德育的关键点, 教师要时刻做个有心 人, 积极挖掘, 有效引导。

3 在实践中渗透德育

“纸上得来终觉浅, 绝知此事要躬行”, 学生在课堂中学到的知识必
须经过实践的检验才会刻骨铭心。为了让学生心怀感恩、志存高远, 教师 要开展一些为学生量身定制的德育活动来激发学生的成长, 这是跳出说教 的最佳方式, 也是知识内化的最佳途径。

比如对学生进行爱的教育, 只靠一节班会课, 只靠教师的讲解是不 够的, 达不到浸润心灵的目的, 教师可以设置一些社会实践活动, 比如 带领学生走进社区, 或者走进 “孤儿院”, 走进 “爱心小屋” 等等场所, 为孤寡老人献爱心, 走进孤儿院, 与那些缺少亲情关爱的孩子成为伙伴 等系列活动, 自然会在孩子们心田播种下最善良的种子。也可以带孩子 走进社会, 对那些辛苦的清洁工叔叔阿姨献上一份爱, 一杯矿泉水, 一 碗绿豆汤都能将人间暖暖的情怀播撒出去, 这就是最好的德育, 也是最 好的教育。

\section{4 在主题活动中升华德育}

人总是要走入社会的, 需要有宽广的胸怀, 需要有不骄不躁的品格, 需要有独立果断的根性, 需要善良真诚, 需要心怀感恩, 需要健康向上的 乐观, 需要永不言败的勇气, 这些都需要通过德育来培养, 为了更好的铸 就学生良好的品行, 开展适当的主题活动是一个很好的切入点, 也是升华 德育的手段。

除了一些常规的主题活动, 教师的智慧在于要捕捉孩子成长的需求, 对他们成长中可能出现的问题进行预判, 比如孩子受挫力差、比如孩子创 新力欠缺、比如孩子意志品质薄弱等等都需要教师关注, 根据学生成长中 遇到的这些这些障碍精心设计关于 “提升学生情商”、“提升学生受挫力”、 “提升学生创新力” 等主题的活动, 通过系列活动的开展, 最大效率的开 展德育活动。

教师要根据不同时期孩子的德育成长需求, 并结合特殊节日, 适当 开发孩子们喜欢的主题活动, 通过系列的主题活动的开展, 使每个孩子真 正成长为有责任、有担当、有创新的新时代的接班人。

德国著名的哲学家说: “教育的唯一工作与全部工作可以总结在这一 概念之中一一道德” 自党的十八大以来, 立德树人作为德育工作根本任务 影响着全国的中小学。树人先立德, 德育是教育之首, 德育不是说教而是 浸润, 需要教师用智慧去展开, 更需要教师用智慧去践行, 教师更要不断 地学习, 在学习中反思并不断提升, 这样才能积极的展开探索和实践, 从 而不断提高德育教育的成效。

\section{[参考文献]}

[1]张春庆. 探讨初中德育工作中如何开展心理健康教育 [ J]. 名师在 线,2020(06):13- 14 .

[2] 荆丽敏.结合思政教育探究大学生语文教学中的德育 [ J].轻纺工 业与技术,2020,49(02):146- 147.

[3]李红宇.浅谈美育与德育的整合 [ J].黑河教育,2020(02):77- 78.

作者简介: 吴要静 (1989) , 女, 汉族, 江苏金湖人, 研究生, 一级教师, 研究方向 : 体育教育训练学, 从事工作 : 小学体育教师。 